\title{
DYSMENORRHEA IN ADOLESCENT POPULATION
}

\section{INTRODUCTION}

The characteristic of the menstrual cycle is on the main criteria of the female reproductive health. Changes in any of these characteristics: the length cycle, the duration and amount of menstrual bleeding, pain, can be a sign of serious problem in young organism or can be a predictor of future disturbance in later life. The prevalence of dysmenorrhea in adolescence worldwide has ranged up to $89.5 \%$ [1-4]. Menstrual pain imposes disabling effects on a girl and can decrease her quality of life. It has been reported to be severe in $10 \%$ of young women, resulting in their incapacitation for the first 3-4 days of their menstrual cycle. Menstrual pain may be accompanied by various symptoms such as vomiting in $84 \%$ of girls, diarrhea (up to $80 \%$ ), vertigo, headache and fainting (up to 20\%) [5]. Thus, dysmenorrhea is medical and social problem.

\section{ANALYSIS OF PUBLISHED DATA}

An epidemiologic study of an adolescent population (age range 12-17 years), Klein and Litt reported that dysmenorrhea had a prevalence of $59.7 \%$ [6]. Of patients reporting pain, $12 \%$ described it as severe, $37 \%$ as moderate, and $49 \%$ as mild. Dysmenorrhea caused $14 \%$ of patients to miss school frequently. Dysmenorrhea in adolescences is strongly associated with chronic pelvic pain in later life [7].

Currently, the most common theory of dysmenorrhea is disorder of synthesis or exchange of prostaglandins. Also syndrome of painful menses is associated with connective tissue dysplasia and congenital or long-term intracellular magnesium insufficiency [8].

Australian population-based survey that include total of 9067 young women showed that smoking and early initiation of smoking are associated with increased risk of chronic dysmenorrhea. Especially those who started to smoke before or by age 13 years, the investigators saw a 59\% higher risk (odds ratio 1.59; $95 \%$ confidence interval 1.18-1.90) after adjusting for other factors [9].

Positive family history and obesity also increase risk for painful menses at adolescent girl.

Diagnosis of dysmenorrhea seems to be very easy, but if it is not covered by the doctor or parents attention, a lot of serious complications can be skipped. The history is critical in establishing the diagnosis of dysmenorrhea and should include an assessment of the onset, duration, type, and severity of pain. A thorough menstrual history is also essential and should include the age at menarche, cycle regularity, cycle length, last menstrual period, and duration and amount of menstrual flow. Determine factors that exacerbate or ameliorate the symptoms, and assess the degree of disruption to school, work, and social activities. It's important to include questions pertaining to sexual abuse because this is reportedly associated with dysmenorrhea and chronic pelvic pain [10].

The key diagnostic issue in dysmenorrhea is differentiating primary dysmenorrhea from secondary dysmenorrhea. It's very important to exclude adenomyosis, cystitis, ovarian cyst, peritonitis, pregnancy, leiomyoma, adrenal insufficiency and adrenal crisis, inflammatory bowel disease, irritable bowel syndrome, pelvic inflammatory disease.

Teenager girls, who have little or no response to nonsteroidal anti-inflammatory drugs (NSAIDs) or combined oral contraceptive pills probably, have endometriosis or chronic inflammatory process of pelvic. A family history may be helpful in differentiating endometriosis from primary dysmenorrheal [11].

The following laboratory studies may be performed to identify or exclude organic causes of secondary dysmenorrheal [12]:

complete blood count with differential to search for evidence of infection or a neoplastic process;

gonococcus and chlamydial cultures, enzyme immunoassay, and DNA probe testing to exclude sexually transmitted infections and pelvic inflammatory disease;

- quantitative human chorionic gonadotropin level to exclude ectopic pregnancy;

- erythrocyte sedimentation rate for subacute salpingitis;

5 urinalysis to exclude urinary tract infection;

- stool guaiac to rule out Gl bleeding;

- cancer antigen 125 (CA-125) assay - this test has relatively low negative predictive value and thus is of limited clinical utility for evaluating dysmenorrheal women.

Over the world definite percentages of women never seek medical attention for dysmenorrhea. They use analgesics drugs and NSAIDs and/or direct application of heat.

Treatment of dysmenorrheal is based on the severity and reasons caused it. Food and Drug Administration (FDA, USA) approved for treatment of dysmenorrhea diclofenac, ibuprofen, ketoprofen, meclofenamate, mefenamic acid and naproxen. Despite some preliminary data suggesting efficacy in patients with primary dysmenorrhea, cyclooxygenase- 2 inhibitors have not been demonstrably superior to conventional NSAIDs [13].

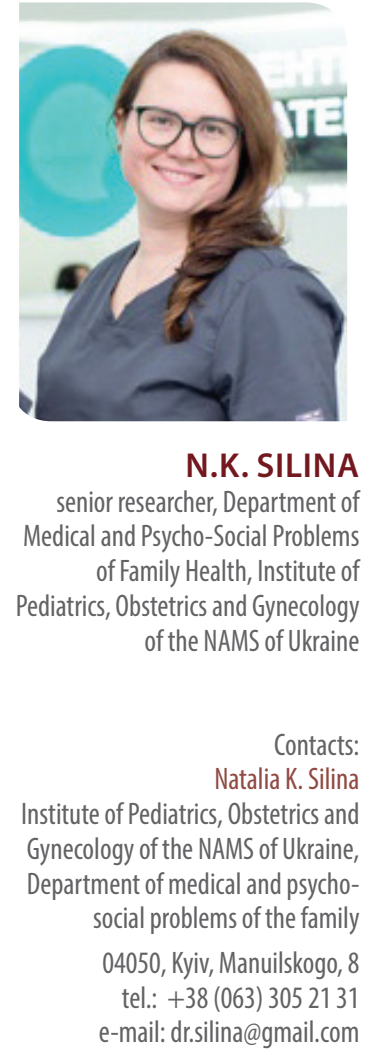

senior researcher, Department of Medical and Psycho-Social Problems of Family Health, Institute of of the NAMS of Ukraine

ntacts:

atalia K. Silina

Institute of Pediatrics, Obstetrics and Gynecology of the NAMS of Ukraine, social problems of the family 04050, Kyiv, Manuilskogo, 8 e-mail:dr.silina@gmail.com 


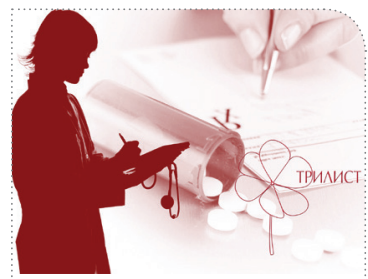

Australian population-based survey that include total of 9067 young women showed that smoking and early initiation of smoking are associated with increased risk of chronic dysmenorrhea. Especially those who started to smoke before or by age 13 years, the investigators saw a $59 \%$ higher risk (odds ratio 1.59; $95 \%$ confidence interval 1.18-1.90) after adjusting for other factors
An update of a Cochrane review showed some evidence of symptomatic benefit in patients who used oral combined pills. Thiamine, fish oil, pyridoxine, magnesium, and vitamin E performed pain reduce [12].

According to randomized trial, that was hold to compare the effect of ginger, zinc sulfate, and placebo on the severity of primary dysmenorrhea in 150 high school students, ginger and zinc had similar positive effects on the improvement of primary dysmenorrheal pain in adolescences [14]. The anti-inflammatory effect of ginger has been reported to result from its efficacy in the inhibition of cyclooxygenase and 5-lipoxygenase, followed by the reduction of leukotriene and prostaglandin synthesis (van Breemen, Tao, \& Li, 2011) and Zinc has been reported to have anti-inflammatory effects and to be a strong antioxidant (Lang et al., 2007, Prasad, 2008). Thus these products can be recommended as alternative method to non-steroid anti-inflammatory drugs, especially in group of girls, who already has gastro-intestinal disorders.

Some trial on behavioral interventions may be effective for dysmenorrhea and reported less time absent from school following treatment wit pain management training compared to a control. One trial showed that relaxation resulted in a decrease in the need for resting time compared to the relaxation and imagery [15].

So dysmenorrhea is a serious medical and social problem that can be managed in different way, which should be diagnosed in time, thus, we decided to analyze the real percentage of dysmenorrhea in adolescent girls in Ukraine.

\section{STUDY OBJECTIVE}

To study the frequency of problems related to menstruation in adolescent girls in urban region of Ukraine.

\section{METHODS}

Study includes girls in the age group 15-17 years who had had menarche for at least one year at the time of study. 532 adolescent girls have been studied. Data was collected by personal interviews on a questionnaire, answered by the girl. The girl's mother also has filled the questionnaire about daughter's health. And one questionnaire was filled by pediatrician as medical epicrisis. The questions covered menstrual function and almost all aspects of girl's life. Analysis was done using SPSS version 12 .

\section{STUDY RESULTS}

The positive is the fact that at the age of 15-17 years $99 \%$ of girls have periods, but almost $20 \%$ of girls have irregular menstruation. Dysmenorrhea occurs in almost $62 \%$ of cases, heavy menstrual bleeding - almost $10 \%$ of girls and too heavy - up to $20.2 \%$ of girls. The average duration of menstruation in girls is 4.5 days (63\% of respondents), $6-7$ days in $31 \%$ and less than three days in $1.5 \%$. The cycle length: $25-28$ days were observed only in $43 \%$ of girls, $29-35$ in $18.8 \%$, less than 21 days in $3.2 \%$, more than 35 days in $3.7 \%$. About $40 \%$ of the teenager girls experienced mild dysmenorrhea, moderate $-30.0 \%$, severe - up to $20 \% .4 .2 \%$ of respondents indicated that they needed medical care during the period.

Analysis of development at girls by Tanner scale showed that harmonious development at age 15-17 years had less than $50 \%$ of girls. We've got approximately the same answers by girl's mothers. But after analyzing the medical epicrisis, we'd found that less than $5 \%$ of girls had any disorders of menstrual function.

Maybe low attention of pediatrics to the girls menstrual function reflects a subjective approach physicians when assessing pain or maybe parents and girls are not used to seek for medical help and prefer to treat themselves or consider any disorders of menstrual function not really important or as a period of the onset of it.

American College of Obstetricians and Gynecologists recommends girls first visit not later than 13 years old. This first visit should include review of normal puberty and menstruation, diet and exercise, healthy sexual decision making, the development of healthy and safe relationships, immunizations, depression, substance use, sexually transmitted infection screening and pregnancy and sexually transmitted infection risks reduction and prevention. Preventive counseling also is beneficial for parents or other supportive adults and can include discussions regarding physical, sexual, and emotional development; signs and symptoms of common conditions affecting adolescents; and encouragement of lifelong healthy behavior. The initial reproductive health visit does not include an internal pelvic examination unless indicated by the medical history.

\section{CONCLUSIONS}

Dysmenorrhea is the commonest disorder, which takes place in almost $62 \%$ of girls at age $15-17$. - General practitioners, pediatricians, adolescent gynecologists should be more active in diagnosis of dysmenorrhea at adolescence girl and as one of the main preventive measures for adolescence girls management of dysmenorrhea recommend lifestyle modification, smoking cessation and exercises.

- Adolescent girls with dysmenorrhea forms a risk group for disorders of reproductive health in later life. 


\section{ЛITEPATYPA/REFERENCES}

1. Sharma, P., Malhotra, C., Taneja, D.K, Saha, R. "Problems related to menstruation amongst adolescent girls." Indian J Pediatr, 75(2) (2008): 125-129.

2. Lee, L.K., Chen, P.C., Lee, K.K., Kaur, J.

"Menstruation among adolescent girls in Malaysia: a cross-sectional school survey." Singapore Med J, 47(10) (2006):869-874.

3. El-Gilany, A.H., Badawi, K., El-Fedawy, S.

"Epidemiology of dysmenorrhoea among adolescent students in Mansoura, Egypt." East Mediterr Health J, 11(1-2) (2005): 155-163.

4. Cakir, M., Mungan, I., Karakas, T., Girisken, I., Okten, A. "Menstrual pattern and common menstrual disorders among university students in Turkey." Pediatr Int, 49(6) (2007): 938-942.

5. Гайнова, И.Г.

Дифференцированный подход к диагностике и лечению дисменореи у девушек: автореф. ... дис. канд. мед. наук / И.Г. Гайнова. - М., 2003.

Gaynova, I.G.

Differentiated approach to diagnosis and treatment of dysmenorrhea girls: author's thesis for the degree of PhD. Moscow (2003).

6. Klein, J.R., Litt, I.F.

"Epidemiology of adolescent dysmenorrhea." Pediatrics, 68(5)

(1981): 661-664.
7. Latthe, P., Mignini, L., et al.

"Factors predisposing women to chronic pelvic pain: systematic review." BMJ, 332(7544) (2006): 749-755.

8. Уварова, Е.В.

Клиника, диагностика и лечение дисменореи у девушек // Е.В. Уварова, И.Г. Гайнова // Медицинский журнал. 2002. 一 № 18, Том 10. - C. 806-809.

Uvarova, E.V., Gaynova, I.G.

"The clinic, diagnostics and treatment of dysmenorrhea in girls." Russian Medical Journal, 18 (Vol. 10) (2002): 806-809.

9. Ju, H., Jones, M., Mishra, G.D.

"Smoking and trajectories of dysmenorrhoea among young Australian women." Tob Control, Nov 11 (2014). [http://press. psprings.co.uk/tc/november/tc051920.pdf]. Last accessed Sept 14, 2015.

10. Jamieson, D.J., Steege, J.F.

"The association of sexual abuse with pelvic pain complaints in a primary care population." Am J Obstet Gynecol, 177(6) (1997): 1408-1412.

11. Simpson, J.L., Elias, S., Malinak, L.R., Buttram, V.C. Jr. "Heritable aspects of endometriosis. I. Genetic studies." Am J Obstet Gynecol, 137(3) (1980): 327-331.

12. Karim Anton Calis, et al.

Dysmenorrhea. [http://emedicine.medscape.com/

article/253812-overview]. Last accessed Sept 14, 2015.
13. Morrison, B.W., Daniels, S.E., Kotey, P., Cantu, N., Seidenberg, B.

"Rofecoxib, a specific cyclooxygenase-2 inhibitor, in primary dysmenorrhea: a randomized controlled trial." Obstet Gynecol, 94(4) (1999): 504-508.

14. Farzaneh Kashefi, et al.

"Comparison of the effect of ginger and zinc sulfate on primary dysmenorrhea. A placebo-controlled randomized trial." Pain Manag Nurs, 15(4) (2014): 826-833.

15. Proctor, M.L., Murphy, P.A., Pattison, H.M., Suckling, J., Farquhar, C.M.

"Behavioural interventions for primary and secondary dysmenorrhoea." Cochrane Database Syst Rev, (2007): CD002248.

\section{DYSMENORRHEA IN ADOLESCENT POPULATION}

N.K. Silina, senior researcher, Department of Medical and Psycho-Social Problems of Family Health, Institute of Pediatrics, Obstetrics and Gynecology of the NAMS of Ukraine

To study the frequency of problems related to menstruation in adolescent girls in urban region of Ukraine. Study includes 532 adolescent girls in the age group 15-17 years who had had menarche for at least one year at the time of study.

It was detected that almost $20 \%$ of girls have irregular menstruation. Dysmenorrhea occurs in almost $62 \%$ of cases, harmonious development at age $15-17$ years had less than $50 \%$ of girls.

So general practitioners, pediatricians, adolescent gynecologists should be more active in diagnosis of dysmenorrhea at adolescence girl. One of the main preventive measures for adolescence girl's management of dysmenorrhea is lifestyle modification, smoking cessation and exercises.

Keywords: adolescence girls, dysmenorrhea, primary dysmenorrhea, secondary dysmenorrhea.

\section{ДИСМЕНОРЕЯ В ПОПУЛЯЦІї ПІДЛІТКІВ}

Н.К. Сіліна, старший науковий співробітник відділення медичних та психосоціальних проблем здоров'я сім'ї, Інститут педіатрії, акушерства та гінекології НАмн України Виконане дослідження вивчало частоту пов'язаних із менструацією проблем у дівчат-підлітків, які проживають у міських регіонах України. У дослідження увійшли 532 дівчинкипідлітка віком 15-17 років, у яких були менструації протягом щонайменше одного року до моменту включення в дослідження.

Виявлено, що близько 20\% дівчат мають нерегулярні менструації. Дисменорея зустрічалася у майже 62\% випадків, гармонійний розвиток у віці 15-17 років спостерігався менш ніж у $50 \%$ дівчаток.

Узв'язку з цим відзначено, що лікарі загальної практики, педіатри, підліткові гінекологи повинні бути активнішими в діагностиці дисменореї у дівчаток-підлітків. Одними з основних профілактичних заходів підліткової дисменореї єзміна способу життя, відмова від паління і фізична активність.

Ключові слова: дівчата-підлітки, дисменорея, первинна дисменорея, вторинна дисменорея.

\section{ДИСМЕНОРЕЯ В ПОПУЛЯЦИИ ПОДРОСТКОВ}

Н.К. Силина, старший научный сотрудник отделения медицинских и психосоциальных проблем здоровья семьи, Институт педиатрии, акушерства и гинекологии НАмН Украины Выполненное исследование изучало частоту проблем, связанных с менструацией, у проживающих в городских регионах Украины девушек-подростков. В исследование вошли 532 девочки-подростка в возрасте 15-17 лет, у которых были менструации в течение как минимум одного года до момента включения в исследование.

0бнаружено, что почти 20\% девушек имеют нерегулярные менструации. Дисменорея встречалась в почти 62\% случаев, гармоничное развитие в возрасте 15-17 лет наблюдалось менее чем у $50 \%$ девочек.

В связи с этим отмечено, что врачи общей практики, педиатры, подростковые гинекологи должны быть более активны в диагностике дисменореи у девочек-подростков. Одними из основных профилактических мер подростковой дисменореи являются изменение образа жизни, отказ от курения и физическая активность.

Ключевые слова: девочки-подростки, дисменорея, первичная дисменорея, вторичная дисменорея. 